\title{
PARTISIPASI MASYARAKAT DALAM PEMBANGUNAN DESA (Studi Kasus Desa Tolonuo, Kecamatan Tobelo Utara, Kabupaten Halmahera Utara)
}

\author{
Ibnu Kanaha \\ FISH, Universitas Halmahera Tabelo \\ Email: ibnukanaha@gmail.com
}

\begin{abstract}
The purpose of this study was to determine the form of community participation in village development in Tolonuo Village, North Tobelo District, North Halmahera Regency. This study uses a qualitative approach, with methods of collecting data through in-depth interviews with village officials, the community, and community leaders. The results of the study show that the Village Head of Tolonuo has played an active role in each program preparation and implementation of the development program, coordinating, monitoring the community to participate and evaluate the implementation of development in the village. The participation of the Tolonuo Village community in village development can be seen based on three types of participation, namely 1). Participation in the form of energy, where the people of Tolonuo Village can complete various jobs on the basis of mutual assistance or self-help with limited funds. 2). Community participation in the form of ideas or thoughts, in the implementation carried out with formal and informal meetings between the community and the village government in discussing and finding solutions and determining the direction of village development policies, and 3). In-kind participation, the community voluntarily contributes material materials to the village head, as needed in the context of implementing development projects in the village.
\end{abstract}

Keywords: participation, community, village development, Tolonuo village

\section{PENDAHULUAN}

Berlakunya Undang-Undang Nomor. 6 Tahun 2014 tentang Desa yang mana ditegaskan pada pasal 78 ayat (1) bahwa pembangunan Desa bertujuan meningkatkan kesejahteraan masyarakat Desa dan kualitas hidup manusia serta penanggulangan kemiskinan melalui pemenuhan kebutuhan dasar, pembangunan sarana dan prasarana Desa, pengembangan potensi ekonomi lokal, serta pemanfaatan sumberdaya alam dan lingkungan secara berkelanjutan. Sebagaimana dimaksud ayat (2) pembangunan Desa meliputi tahapan perencanaan pelaksanaan, dan pengawasan, dan ayat (3) pembangunan desa sebagai mana ayat 1 dan 2 adalah mengedepankan kebersamaan, kekeluargaan, dan kegotongroyongan guna mewujudkan perdamayan dan keadilan sosial.

Tujuan yang ingin dicapai sebelumnya direncanakan yakni mengembangkan kemampuan masyarakat dapat berfungsi secara interaktif tujuan akhir tersebut juga dapat melibatkan diri dalam cara kerja sama atas dasar swakarya dan menggunakan proses atau prosedur yang demokrasitif sebagai tujuan pokok Arbit Sanit (1985).

Dari permasalahan yang selalu dihadapi masyarakat kurang memberikan motifasi atau dorongan dari pihak pemerintah sehingga kesadaran partisipasi warga masyarakat lemah, karna masyarakat selalu diikat oleh tradisi yang tertutup terhadap pengaruh dari luar, yang harus dilakukan pemerintah desa mendorong masyarakat berpartisipasi dalam pembangunan, yaitu dengan memotivasi warga masyarakat agar terlibat aktif dalam proses perubahan. Partisipasi aktif dalam pembangunan menjadi tujuan utama dalam proses perubahan.

Dengan kesadaran dan motivasi tentu terlibat aktif dalam perubahan dengan prinsip yang partisipatif dengan menegaskan rakyat 
harus menjadi pelaku utama (subjek) dalam pembangunan. Hal ini membutukan strategis yang lebih intensif retrukturusasi system social. Arbit Sanit (1985).

Berkaitan dengan proses pembangunan desa, ada dua unsur utama yaitu swadaya masyarakat dan pembinaan masyarakat dan pemerintahan. Agar pembangunan bisa terlaksana dengan baik tentunya harus ada kerja sama yang baik antara pemerintah dan masyarakat sehingga dapat terlaksana dengan baik. Pemerintah desa dalam hal ini kepala desa sebagai pimpina serta memiliki tugas dan kewajiban dalam menyelenggarakan urusan pembangunan di Desa Tolonuo, Kecamatan Tobelo Utara terlebih khusus mengarahkan masyarakat serta mempengaruhi agar tingkat kesadaran masyarakat untuk berpartisipasi dalam pelaksanan perencanaan pembangunan di Desa Tolonuo, Kecamatan Tobelo Utara yang lebih baik lagi sesuai dengan Undang-Undang Nomor 6 Tahun 2014 tentang Desa, sehingga dapat tercapai demi mewujudkan perencanaan pembangunan.

Di dalam mewujudkan suatu pembangunan yang berhasil, ikut sertanya masyarakat luas sangatlah penting, bukan hanya di dalam mengawasi aparatur pemerintah seperti birokrasi pemerintahan, tentu keterlibatan keseluruhan masyarakat sebagai sebuah masalah yang dihadapinya dan pencarian jawaban bagi masalah tersebut.persolan motivasi, nilai, maksud dan tujuan

Desa Tolonuo, Kecamatan Tobelo Utara Kabupaten Halmahera Utara merupakan salah satu desa yang memiliki sumberdaya alam, yang jika di kelola dengan baik akan mendatang keuntungan untuk desa. Untuk mengarahkan masyarakat dalam partisipasinya terhadap pembangunan, diperlukan adanya tenaga atau unsur yang menggerahkan dan mengarahkan kemampuan masyarakat untuk dapat mewujudkan cita-cita pembangunan, maka Kepala Desa sebagai penyeneggara pemerintahan memegang peranan yang sangat penting dan sebagai pimpinan tertinggi dan penanggungjawab pelaksanaan pemerintahan dan pembangunan, harus mampu menggembangkan tugas yang dibebankan kepada yang saling kait-mengkait termasuk tugas pembangunan yang multi dimensional.

Dari pokok pikiran tersebut diatas maka penulis jadi alasan untuk mengkaji Partisipasi Masyarakat dalam Pembangunan (Studi Kasus Desa Tolonuo, Kecamatan Tobelo Utara, Kabupaten Halmahera Utara). Dengan rumusan masalah 1). Peran Pemerintah Desa Dalam Pembangunan Desa Tolonu, Kecamatan Tobelo Utara Kabupaten Halmahera Utara)?

2). Partisipasi Masyarakat Dalam Pembangunan Desa Tolonuo, Kecamatan Tobelo Utara Kabupaten Halmahera Utara)?.

\section{TINJAUAN PUSTAKA}

\section{Partisipasi Masyarakat}

Partisipasi dapat didefinisikan sebagai keterlibatan mental atau pikiran atau moral dan perasaan di dalam situasi kelompok yang mendorong untuk memberikan sumbangan kepada kelompok dalam usaha mencapai tujuan serta turut bertanggungjawab terhadap usaha yang bersangkutan. (Santoso, 1988). Berdasarkan pendapat tersebut di atas, maka partisipasi itu tidak berdasarkan keterlibatan secara fisik dalam pekerjaannya tetapi menyangkut keterlibatan diri sesseorang sehingga akan menimbulkan tanggungjawab dan sumbangan yang besar terhadap kelompok. Partisipasi berarti ada keikutsertaan, mengawasi, mengontrol dan mempengaruhi masyarakat dalam suatu kegiatan mulai dari perencanaan sampai dengan evaluasi pelaksanaan.

Defenisi yang dikemukakan oleh Andrea Cornwall bahwa partisipasi adalah proses tumbunya kesadaran terhadap hubungan antara masyarakat, yaitu keterlibatan antara kelompokkelompok social dan komunitas dengan pengambilan kebijakan dan lembaga-lembaga jasa lain. (Cornwall, 2011).

Bila kita hubungkan dengan

pembangunan untuk mencapai tujuan pembangunan nasional yakni meningkatkan taraf hidup masyarakat menuju terwujudnya masyarakat yang adil dan makmur berdasarkan pancasila ke lima dalam UUD 1945 masyarakat dalam kedudukannya sebagai subyek pembangunan terhadap apa yang dibutuhkan 
dalam memberikan sumbangan dalam pembangunan.

Kesedian memberikan sumbangan ini bukan lahir begitu saja, akan tetapi terdorong oleh motivasi-motivasi tertentu yang dicapai. Disamping itu juga ada upaya-upaya yang dilakukan oleh pemerintah dalam membangkitkan kesadaran masyarakat dalam pembangunan adalah fungsi pemerintah.

Menurut Wazir partisipasi biasa diartikan sebagai keterlibatan seseorang secara sadar ke dalam interaksi sosial dalam situasi tertentu. Dengan pengertian itu seseorang bisa berpartisipasi bila ia menemukan dirinya dengan atau dalam kelompok, melalui berbagai proses berbagai dengan orang lain dalam hal nilai, tradisi, perasaan, kesetiaan, kepatuhan dan tanggungjawab bersama.

Sedangkan menurut Rahardjo (2006), partisipasi rakyat dalam pembangunan sebagai dukungan rakyat terhadap rencana/proyek yang direncanakan dan ditentukan tujuannya oleh perencana, dengan ukuran tinggi rendanya partisipasi rakyat dalam defenisi ini diukur dengan kemampuan dan kemauan rakyat dalam melaksanakan pembangunan. Partisipasi rakyat dalam pembangunan merupakan kerjasama yang erat antara perencanaan dan rakyat dalam merencanakan, melaksanakan, melestarikan dan mengembangkan hasil pembangunan yang telah dicapai. Ukuran tinggi dan rendanya rakyat untuk menanggung biaya pembangunan. Tetapi juga dengan ada tindakannya hak rakyat untuk ikut menentukan arah dan tujuan proyek yang akan dibangun di wilayahnya. Ukuran lain yang dapat digunakan adalah ada tidak kemauan rakyat untuk secara mandiri melestarikan dan mengembangkan hasil proyek itu.

Dari beberapa mengungkapkan defenisi partisipasi di atas, dapat dibuat kesimpulan bahwa partisipasi adalah suatu wujud dari peran serta masyarakat dalam aktivitas dalam pelaksanaan pembangunan untuk mencapai tujuan pembangunan masyarakat, keterlibatan aktif dari seseorang, atau sekelompok orang masyarakat secara sadar untuk berkontribusi secara sukarela dalam program pembangunan dan terlibat melai dari perencanaan, pelaksanaan, monitoring sampai pada tahapan evaluasi.

\section{Bentuk Partisipasi Masyarakat}

Satropoetro (1988) mengemukakan tentang bentuk partisipasi yaitu:

1. Konsultasi, biasanya dalam bentuk jasa.

2. Sumbangan spontan berupa uang dan barang.

3. Mendirikn proyek individu atau instansi yang berada di luar lingkungan tertentu (dermawan atau pihak ketiga), merupakan salah satu partisipasi dan langsung akan dirasakan oleh masyarakat itu sendiri dalam pembangunan desa tersebut.

4. Mendirikan proyek yang sifatnya berdikari dan dibiayai sepenuhnya oleh komoniti (biasanya diputuskan oleh dalam rapat desa yang menentukan anggarannya).

5. Sumbangan dalam bentuk kerja, yang biasanya dilakukan oleh tenaga ahli setempat. Bentuk kerja yang disumbangkan oleh masyarakat akan memperingan pembangunan yang diselenggarakan di desa tersebut.

6. Melakukan aksi massa.

7. Mengadakan pembangunan dilaksanakan keluarga sendiri.

8. Membangun proyek komoniti yang sifatnya otonom.

Dalam hal partisipasi masyarakat pembangunan desa. Ndraha (1987), partisipasi dalam bentuk swadaya murni dari masyarakat dalam hubungan dengan pemerintah desa, seperti jasa/tenaga, barang maupun uang.

1. Partisipasi dalam penerimaan/ pemberian informasi.

2. Partisipasi dalam bentuk pemberian gagasan.

3. Partisipasi dalam bentuk menilai pembangunan.

4. Partisipasi dalam bentuk pelaksanaan operasional pembangunan.

Dari pendapat Ndraha di atas bahwa partisipasi masyarakat pembngunan desa sangat luas dalam hal perumusan, perencanaan, pengawasan, pelaksanaan sserta pemanfaatan hasil pembangunan perlu dilibatkan.dengan 
dilakukan dengan swadaya gotong royong. Partisipasi masyarakat dalam bentuk swadaya gotong royong merupakan modal utama dan potensi yang esensial dalam pelaksanaan pembangunan desa yang selanjutnya tumbu dan berkembang menjadi dasar kelangsungan pembangunan nasional.

\section{Faktor Yang Mempengaruhi Partisipasi Masyarakat}

Ada beberapa faktor yang mempengaruhi perlu diperhatikan dalam upaya peningkatan partisipasi masyarakat, baik berupa faktor pendorong maupaun faktor penghambantnya. Faktor pendorong yang dapat mempengaruhi partisipasi masyarakat, sebagaimana yang dikemukakan oleh Subrata \& Atmaja (Hidayat, 2002)

1. Adanya interes dan partisipan, mersa tertarik kedalam partisipasi pembangunan

2. Hadiah dari suatu kegiatan, merasa memiliki adanya imbalan atau honor

3. Adanya keuntungan dari kegiatan. Merasa diuntungkan bagi diri sendiri dan masyarakat

4. Motivasi dari luar. Adanya memberikan harapat dari desa tetangga untuk bersama-sama bergabung dalam melakukan sebua kegiatan.

Mengikut pendapat tersebut yang dapat mewarnai dan turut berperang dalam menumbuhkan partisipasi masyarakat yaitu pemuka masyarakat atau toko masyarakat, faktor lain yang dapat mewarnai dab turut berperang dalam menumbuhkan partisipasi masyarakat, Wisnu menjelaskan, di dalam pembangunan masyarakat peran mereka yang tergolong informal pemimpin sangat berperang besarnya, mereka mempunyai pengaruh yang besar terhadap rakyat didesanya. Kadang-kadang suatu program pemerintah dapat gagal karena tidak mengikut sertakan para pemuka masyarakat, dengan demikian dapat diketahui pula bahwa partisipasi masyarakat pun dipengaruhi pula oleh adanya seseorang yang menjadi pendorong atau motivator dalam suatu kegiatan.

\section{Konsep Pembangunan Desa}

Para ahli banyak yang mengunanakan istilha dalam mendefenisikan pembangunan antara lain dengan menggunakan kata modernisasi, perubahan sosial, dan lain sebagainya Michael Todaro (Konenjaraningrat, 1979).

Sedangkan menurut Sondang P. Siagian (2003) pembangunan sebagai suatu perubahan yang berencana yang dilakukan secara sadar oleh suatu bangsa, negara dan pemerintah menuju moderenisasi dalam rangka pembinaan bangsa. Sebagai upaya pembangunan bangsa, ekonomi, politik sosial, kebudayaan dan pertahanan keamanann serta hubungan antra bangsa.

Keberhasilan penyelenggaraan pembangunan dalam segi kehidupan dan penghidupan bangsa menuju komitmen seluruh komponen masyarakat idealnya, berdasarkan strategi dan rencana pembangunan yang ditetapkan oleh pemerintah, semua warga masyarakat turut menjadi "pemain" dan tidak ada yang sekedar menjadi "penonton". Memang benar bahwa jenis, intensitas, dan ekstensitas ketertiban berbagai pihak berbeda-beda karen pengetahuan, keterampilan pemikiran intelektual, waktu, tenaga, dan kesempatan yang di miliki juga beraneka ragam. Meskipun penyenlenggaraan kegiatan pembangunan tidak menggunakan pendekatan, "elitist". Kelompok elit dalam masyarakat harus memberikan kontribusi yang lebih substansial dibandingkan dengan para warga masyarakat yang lain,

Pembangunan desa usaha meningkatkan harkat martabat masyarakat yang dalam kondisi yang tidak mampu melepaskan diri dari perangkat kemiskinan dan keterbelakangan, artinya mempukan atau memandirikan mereka, dimulai dari proses pembagnunan dengan berpijak pada pembangunan masyarakat, Bintoro (1985). Dari berbagai defenisi yang telah dikemukakan, maka dapat diambil kesimpulan bahwa pembangunan ditujukan untuk meningkatkan kemampuan, kebersamaan, kemandirian dan saling ketergantunagan masyarakat, yang pada akhirnya untuk meningkatkan masyarakat itu sendiri. 


\section{METODE PENELITIAN}

Jenis Penelitian yang digunakan dalam penelitian ini menggunakan kualitatif. Bogdan (2004) berpendapat bahwa penelitian kualitatif adalah suatu penelitian yang dilakukan pada konteks dari suatu keputusan yang alami dengan memberi tekanan pada interaksi dan proses yang berupaya untuk mencari makna-makna yang mendasari tingkah-laku subjek, dan hasil akhirnya tidak dianalisis dengan bantuan statistik atau cara hitung lainnya.

Sumber data dalam penelitian ini adalah data primer yang diperoleh melalui observasi dan wawancara mendalam terhadap informan, dengan key informan adalah aparat desa dan masyarakat desa.

Analisis data dalam penelitian ini menggunakan metode Milis dan Huberman (1992), yaitu:

1. Reduksi Data

Data yang diperoleh di lapangan penelitian dituangkan dalam uraian atau laporan yang lengkap dan terpeinci. Kemudian laporan tersebut direduksi dan memilah data-data kemudian dipilih data yang relevan untuk dikaji berdasarkan fokus dalam penelitian. Dalam mereduksi data penelitian ini dilakukan dari awal hingga akhir penelitian.

2. Penyajian Data

Penyajian data menggambarkan secara keseluruhan penelitian data yang disajikan dalam penelitian disesuaikan dengan data di lapangan dan informasi yang diperoleh melalui informan. Sehingga laporan hasil penelitian yang disajikan benar-benar valid dan dapat dipertanggung jawabkan dengan tidak melakukan interaksi sehingga pembaca dapat mengambil kesimpulan sendiri mengenai laporan atau hasil penelitian tersebut.

3. Verifaksi/Menarik Kesimpulan

Penarikan kesimpulan dilakukan sejak awal penelitian sampai penelitian berakhir.Peneliti selalu berusaha menganalisis serta mencari makna dari data yang dikumpulkan, penarikan kesimpulan dilakukan dengan mencari pola dan hubungan data yang relevan kemudian dituangkan dalam kesimpulan yang masih bersifat tentatif hingga pada kesimpulan akhir.

\section{HASIL DAN PEMBAHASAN}

\section{A. Peran Pemerintah Desa}

Wawancara dilakukan dengan berbagai pihak baik aparat desa maupun masyarakat tentang peran pemerintah desa dalam menumbuhkan partisipasi masyarakat dalam pembangunan. Berikut ini adalah hasil wawancara tentang partisipasi pembangunan desa di Desa Tolonuo. Berdasarkan informasi dari hasil wawancara dengan Bapak SK Selaku Kaur Pembangunan.

Bagaimana Peran Pemerintah Desa dalam Pembangunan di Desa Tolonuo ?.

Kepala desa maupun aparatur pemerintah desa mampu menjalankan peran dan fungsi dalam hal penyelenggaran pembangunan yaitu selalu berkordinasi aktif dengan perangkatnya dalam pelaksanaan program pembangunan dan beliu memiliki semangat kerja yang tinggi. (Wawancara terhadap informan SK pada Hari Senin 1 Mei, 2017,Jam 8.00 WIT).

Dari hasil wawan cara tersebut diatas terlihat jelas Kepala Desa berperan aktif dalam setiap penyusunan program maupun pelaksanaan program pembangunan, mengkordinasikan, memantau masyarakat untuk berpartisipasi serta mengevaluasi pelaksanaan pembangunan di desa. Wawancara selanjutnya dengan Kepala Desa Bapak HM.

$\begin{array}{llr}\text { Bagaimana menerapkan } & \text { partisipasi } \\ \text { masyarakat dalam } & \text { menunjang } \\ \text { pembangunan di Desa } & \text { Tolonuo } \\ \text { Kecamatan Tabelo Utara? } & \end{array}$


Partisipasi masyarakat dalam pembangunan desa sangatlah penting, oleh karena semua itu demi kesejahteraan dan kemajuan masyarakat dan pemerintah Desa Tolonuo, sehingga pemerintah juga turut mengikuti sertakan dalam menompang program-program pemerintah yang sangat perlu dilakukan, mengingat program tersebut berdampak pada masyarakatnya Desa Tolonuo, demikian ungkapannya. (Wawancara terhadap informan HM pada Hari Senin 01 Mei, 2017 Jam 8.00 WIT).

Dari hasil wawancara di atas menunjukan bahwa, pemerintah di Desa Tolonuo Kecamatan Tobelo Utara dapat dilakukan dengan baik, karena adanya komunikasi yang baik antara masyarakat dan Kepala Desa dimana Kepala Desa Tolonuo mengikutisertakan dalam program pemerintah desa karena hal itu sangat perlu dilakukan, serta Kepala Desa memiliki kemampuan dalam berpartisipasi aktif dalam setiap penyelenggaraan Pembanunan Desa, mengingat program tersebut berdampak pada masyarakat setempat. Untuk meneliti lebih jauh wawancara dilanjutkan kepada informan selanjutnya yaitu salah satu Anggota BPD Bapak HP.

Bagaimana peran Kepala Desa Tolonuo menerapkan partisipasi masyarakat dalam menunjang pembangunan di Desa Tolonuo Kecamatan Tabeleo Utara?

Mengenai peran maupun sikap Kepala Desa dalam menjalankan pemerintahan serta pembangunan sangatlah terbukaan dan demokratis serta dinamis. Hal ini dirasakan oleh perangkat desa dalam pertemua atau rapat evaluasi kerja setiap program yang dijalankan dan dievaluasi selalu bersama-sama dengan kami setiap dari program pemerintah desa, (Wawancara terhadap informan HP pada Hari Selasa, 02 Mei, 2017 Jam 9.00 WIT).

Hasil wawancara di atas menunjukan bahwah Kepala Desa sudah tepat menjalankan peranya aktif dalam setiap pelaksanaan pembangunan serta keterbukaan kepada perangkatnya, masyarakat dengan indikatoranya selalu melakukan rapat evaluasi kerja dari tahapan maupun berakhirnya proses kegiatan. Peneliti melanjutkan wawancara kepada Bapak MK Selaku Sekretaris Desa.

Bagaimana Partisipasi Masyarakat dalam pembangunan di Desa Tolonuo?

Partisipasi adalah keterlibatan aktif dari seseorang, atau sekelompok orang atau masyarakat secara sadar untuk berkontribusi secara sukarela dalam program pemangunan dan terlibat mulai dari perencanaan, pelaksanaan, monitoring sampai pada tahapan evaluasi. (Wawancara terhadap informan MK pada Hari Rabu, 03 Mei, 2017 Jam 8.00 WIT).

Jadi masyarakat kami khususnya Desa Tolonuo selama Undang-Undang No. 6 Tahun 2014 tentang Desa, kami telah melakukan sosialisasi undang-undang tersebut, masyarakat mulai sadar dan mereka lebih aktif untuk terlibat dalam program kegiatan pelaksanaan pembangunan desa, dan juga setiap program yang diturunkan dari pemeintah kecamatan maupun pemerintah kabupaten, seperti sekarang ini kami dapatkan anggaran dari pemerintah kabupaten lima ratus juta rupiah, masyarakat lebih senang, awalnya sebelum kami usulkan saya panggil dan kami rapatkan untuk menyusun program tersebut.

Partisipasi aktif dan kita seтиa melakukan motivasi, serta dorongan dari Kepala Desa serta memberikan panutan atau pembinaan merupakan salah satu unsur yang sangat penting dalam pembangunan masyarakatnya, dengan tujuannya masyarakat tahu dan mengerti apa yang harus dikerjakan dan timbulnya kemauan untuk mengerjakan sesuai dengan kehendaknya kita.. (Wawancara 
terhadap informan MK pada Hari Rabu, 03 Mei, 2017 Jam 9.00 WIT).

Wawancara tersebut menunjukan bahwa masyarakat Desa Tolonuo sangat berpartisipasi dalam pembangunan dan mendukun program Kepala Desa menyangkut Program Desa maupun Kecamatan serta Kabupaten Halmahera Utara. Selain itu terdapat juga pendapat masyarakat dengan insial Bapak LN.

Contoh dalam proses pengambilan keputusan di desa, Kepala Desa selalu mendengar dan berusaha menampung aspirasi masyarakat lewat forum-forum, sehingga apa yang dismpaikan oleh Kepala Desa kami selalu mengikuti apa yang diprogramkan Kepala Desa. (Wawancara terhadap informan LN pada Hari Rabu, 03 Mei 2017 Jam 10.00 WIT).

Pemerintah Desa Tolonuo merupakan pemengang kendali dalam hal pembangunan di Desa Tolonuo, oleh karena itu Kepala Desa beserta jajarannya merupakan penanggungjawab di desa atas jalannya roda pemerintahan dan roda pembangunan sehinngga maju mundurnya pembangunan di Desa Tolonu tergantung dari kinerja Pemerintah Desa Tolonuo, Kecamatan Tobelo Utara dalam mempengaruhi masyarakat untuk ikut serta di dalam pembangunan. Hal ini menunjukan bahwa Kepala Desa dalam proses pelaksanaan pembangunan non fisik maupun fisik dengan cara selalu melibatkan unsur masyarakat dalam setiap ada kegiatan dan pengambilan keputusan, sehingg masyarakat rasa memiliki rasa kekeluargaan dan jiwa kebersamaannya. Agar peran pemerintah desa dapat mempengaruhi masyarakat dalam pembangunan dapat dilihat melalui indicatorindikator perannya sebagai pembina, pengayom, dan pelayanan masyarakat.

\section{B. Partisipasi dalam Pembanguanan Desa}

Dalam teori partisipasi masyarakat, Sastroputro (1988) partisipasi meliputi beberapa dimensi yaitu 1). Sumbangan pikiran ide atau gagasan. 2). Sumbangan materi, dana, barang, alat. 3). Sumbangan tenaga, bekerja atau memberi kerja. 4). Memanfaatkan atau melaksanakan pelayanan pembangunan. Akan tetapi dalam penelitian ini membahas hanya pada tiga dimensi partisipasi yaitu:

\section{Partisipasi Dalam Bentuk Tenaga}

Partisipasi dalam bentuk tenaga adalah merupakan salah satu bentuk partisipasi dari masyarakat Desa Tolonuo yang sangat potensial diarahkan dalam proses pembangunan desa, khususnya dalam pengerjaan proyek-proyek fisik. Bisa kita melihat bahwa masyarakat Indonesia, khususnya masyarakat Desa Tolonuo dapat menyelesaikan berbagai pekerjaan atas dasar gotong-royong atau swadaya dengan dana yang terbatas, tapi mereka mampu dan berhasil menyelesaikan pekerjaan-pekerjaan yang ada. Kenyataan ini menunjukan bahwa mengarahkan masyarakat desa khususnya Desa Tolonuo untuk berpartisipasi dalam pembangunan desanya tidak semata-mata tergantung pada aspek anggaran.

\section{Partisipasi dalam bentuk Ide atau Pikiran}

Partisipasi masyarakat dalam pembangunan tidak terbatas pada pelaksanaan program, tetapi juga dalam menyambung ide atau pikiran serta proses pengambilan keputusan dan pemilihan program yang akan dilaksanakan, kebijaksanaan semacam ini memungkinkan masyarakat secara luas berpartisipasi dalam pelaksanaannya juga dapat mendatang sisi positif yang lain.

Sisi positif yang lain adalah tersalurkannya aspirasi serta kepentingan seluruh lapisan masyarakat serta terbinanya kreativitas dan inisiatif warga masyarakat untuk ikut serta menentukan suatu program pembangunan yang bermanfaat. Partisipasi masyarakat dalam Bentuk Ide atau Pikiran pelaksanaanya khususnya di Desa Tolonuo dilakukan dengan pertemuan formal dan informal antara masyarakat dan Pemerintah Desa dalam membahas dan mencari solusi dan menentukan kebijakan. Sisi positif yang lain adalah tersalurkannya aspirasi serta kepentingan seluruh lapisan masyarakat serta terbinanya kreativitas dan inisiatif warga masyarakat untuk ikut serta menentukan suatu program pembangunan yang bermanfaat. Partisipasi masyarakat dalam bentuk ide atau pikiran 
pelaksanaanya khususnya di Desa Tolonuo dilakukan dengan pertemuan formal dan informal antara masyarakat dan Pemerintah Desa dalam membahas dan mencari solusi dan menentukan kebijakan. Hal ini sesuai dengan yang dikemukan oleh salah seorang informan Desa Tolonuo Bapak RK mengatakan bahwa:

"Masyarakat Desa Tolonuo sering menyumbang ide atau pikiran dalam pembangunan, apalagi dipancing dengan suatu masalah yang mendesak di Desa Tolonuo, tidak hnaya dalam bentuk rapatrapat dalam kantor desa, tapi di luar kantor pung mereka menyumbang ide/pikiran berkaitan dengan program apapun mereka lakukan. (Wawancara terhadap informan RK. pada Hari Kamis 5 Mei 2017 Jam 11.00 WIT).

Partisipasi ide atau pikiran, dikaji dua penyaluran aspirasi yang dilakukan dalam bentuk formal dimana dilakukan dalam rapatrapat desa atau pertemuan formal lainnya, bertujuan semua masyarakat ikut dalam rapat desa maka pemerintah setempat melakukan pendekatan dalam bentuk informal yaitu pertemuan diluar forum formal dengan aparat pemerintah desa dengan masyarakat dan tokohtokoh masyarakat dalam pengambilan kebijakan di tingkat desa, guna menyerap aspirasi dari masyarakat demi pengembangan dan pembangunan desa yang berkesinambungan. Partisipasi masyarakat dalam menyumbang ide atau pikiran tidak selalu mudah dilaksanakan, berdasarkan wawancara dengan Bapak NR, selaku Ketua RT. 2 mengatakan bahwa:

Pelaksanaan rapat atau pertemuan secara formal tidak semua masyarakat maupun elemen masyarakat yang kami undang dalam mengikuti rapat desa yang diundang hanya Toko masyarakat, Ketua $B P D$ dan Anggota, Ketua RT, 2 RW dan pemuda, ana-nan mahasiswa sementara mereka libur mereda ada di desa. (Wawancara terhadap informan NR pada Hari Kamis 5 Mei 2017 Jam 11.30 WIT).

Pendapat tersebut sama dengan Bapak UT, selaku Wakil Ketua BPD Desa Tolonuo serta sekaligus Toko Agama maupun Toko Pemuda mengatakan bahwa:

Memang betul kadang kala rapat seluru warga tidak diundang, dengan pertimbangan masyarakat mempunyai kesibukan dikebun masing-masing, akan tetapi dalam penyampaian aspirasi bisa kami salurkan melalui Ketua BPD dan jajarannya, atau ketua $R T$ - $R W$ masingmasing nanti ketua-ketua $R T \& R W$ menyampaikan dalam suatu rapat desa. (Wawancara terhadap informan RK. pada Hari Kamis 5 Mei 2017 Jam 11.45 WIT).

Sesuai dengan penjelasan dan arahan kepala desa, tidak ada larangan bagi masyarakat untuk ikut dalam rapat, dengan asumsinya bahwa tidak hanya elemen-elemen yang diundang, tokoh masyarakat, anggota BPD dan Ketua RT-RW karena mereka sebagai perwakilan.

\section{Partisipasi Dalam Bentuk Barang}

Partisipasi dalam bentuk barang yang dimaksudkan adalah barang-barang yang dimiliki oleh masyarakat yang secara sukarela disumbangkan kepada kepala desa dalam rangka pelaksanaan proyek-proyek di desa. Seperti yang telah dikemukakan bahwa proyek pembangunan fisik memiliki dana yang besar. Salah seorang informan yang menyampaikan bahwa untuk pembuatan jalan setapak yang memadai, tentu dana yang dibutukan juga harus besar. Oleh karena itu diharapkan kesediaan masyarakat untuk menyumbangkan bahan-bahan tertentu yang dibutukan dalam rangka pembangunan fisik tersebut. Arahan ini ternyata mendapatkan sambutan positif dari berbagai kalangan masyarakat maupun tokoh-tokoh masyarakat, sambutan positif yang dimaksudkan adalah pemberian suka rela bahan bangunan seperti seperti kerikil, pasir dan semen dan lainnya, pada saat dibutukan dalam pekerjaan pembangunan tersebut.

\section{KESIMPULAN}

Peran pemerintah desa melalui Kepala Desa Tolonuo telah berperan aktif dalam setiap penyusunan program maupun pelaksanaan 
program pembangunan, mengkordinasikan, memantau masyarakat untuk berpartisipasi serta mengevaluasi pelaksanaan pembangunan di desa. Selain itu masyarakat Desa Tolonuo sangat berpartisipasi dalam pembangunan dan selalu mendukun program kepala desa.

Partisipasi masyarakat Desa Tolonuo dalam pembangunan desa, dapat dilihat berdasarkan tiga jenis partisipasi yaitu 1). Partisipasi dalam bentuk tenaga, dimana masyarakat Desa Tolonuo dapat menyelesaikan berbagai pekerjaan atas dasar gotong-royong atau swadaya dengan dana yang terbatas. 2). Partisipasi masyarakat dalam bentuk Ide atau pikiran, dalam pelaksanaanya dilakukan dengan pertemuan formal dan informal antara masyarakat dan pemerintah desa dalam membahas dan mencari solusi dan menentukan arah kebijakan pembangunan desa, dan 3). Partisipasi dalam bentuk barang, masyarakat secara sukarela menyumbang bahan bahan material kepada kepala desa, sesuai kebutuhan dalam rangka pelaksanaan proyek-proyek pembangunan di desa.

\section{REFERENSI}

Arbit Sanit. 1985. Sistem Politik Indonesia. Jakarta: Rajawali Press.

Barawi dan Suwandi. 2008. Memahami Penelitian Kualitiatif. Jakarta: PT Rineka Cipta Pressindo.

Karianga, Hendra. Cornwall, Andrea. 2011. Partisipasi Masyarakat dalam Pengelolaan Keuangan Daerah. Bandung: PT. Alumni.

Michael Todaro. 1979. Pembangunan dan Partisipasi. Jakarta: PT. Gramedia.

Ndraha, Talizuduhu. 1987. Pembangunan Masyarakat, Mempersiapkan Masyarakat Tinggal Landas. Jakarta: PT. Bina Aksara.
Sastropoetro, Santoso R.A. 1988. Partisipasi, Komonikasi, Persuasi, dan Disiplin dalam Pembangunan Nasional. Bandung: Alumni.

Siagian, Sondang P. 2003. Administrasi Pemganunan Konsep Dimensi. Jakarta: PT. Bumi Aksara

Slamet, Yulius. 1994. Pembangunan Masyarakat Berwawasan Partisipasi. Surakarta: UNSPress.

Soetrisno Adisasmita, Rahardjo 2006. Membangun Desa Partisipatif. Yogyakarta: Graha Ilmu.

Subrata. Atmaja. Hidayat, Wisnu Dkk, (2002). Pembangunan Partisipasif. Yokyakarta: YPAPI.

Undang-Undang Nomor 6 Tahun 2014 Tentang Pemerintahan Desa. Bandung: Citra Utama. 